\title{
URINARY STEROID EXCRETION IN RESPONSE TO ENDOGENOUS AND EXOGENOUS GONADOTROPHIN STIMULATION OF CRYPTORCHID TESTES IN THE PIG
}

\author{
R. M. LIPTRAP AND J. I. RAESIDE \\ Department of Biomedical Sciences, University of Guelph, \\ Guelph, Ontario, Canada
}

(Received 19th May 1970)

\begin{abstract}
Summary. Urinary levels of DHA and oestrogens were determined in normal, unilaterally and bilaterally cryptorchid boars and in such animals following hemicastration or treatment with HCG. Removal of one testis from normal boars or the abdominal testis from unilaterally cryptorchid boars did not appreciably alter the urinary levels of DHA and oestrogens. Removal of the scrotal testis of unilaterally cryptorchid boars or one abdominal testis of bilaterally cryptorchid boars resulted in a significant drop in urinary steroid values. Except for one boar, DHA returned to within control levels in 2 months while oestrogen values were significantly lower in two animals and significantly higher in one animal at 2 months. HCG treatment caused a highly significant increase in DHA and oestrogen excretion in a normal boar and a unilaterally cryptorchid boar with a scrotal testis remaining after hemicastration. Boars with bilateral cryptorchid testes and a boar with an abdominal testis remaining after hemicastration showed a limited response to HCG injections. The results suggest that the cryptorchid testis of the pig is able to compensate for the loss of the contralateral gonad but the limit of response to gonadotrophin is very much lower and the time of response is slower than that exhibited by the scrotal testis.
\end{abstract}

\section{INTRODUCTION}

Gryptorchidism is a condition of considerable clinical interest and also provides an experimental model suitable for some studies of testicular-pituitary relationships in the absence of spermatogenesis. Androgen production by the cryptorchid testis appears to be reduced in the rat (Clegg, 1960; Llaurado \& Dominguez, 1963; Morehead \& Morgan, 1967), rabbit (Hall, 1965; Free, Vera Gruz, Johnson \& Gomes, 1968), dog (Eik-Nes, 1966) and man (Engberg, 1949). Eik-Nes (1962) has shown that steroid production by the testis is under the control of interstitial cell-stimulating hormone (ICSH). It has been reported that pituitary levels (Steinberger \& Duckett, 1966) and plasma levels (Johnson, 1966) of IcSH are elevated in the cryptorchid rat. Karg \& Kronthaler (1960) 
observed a marked reduction in the nuclear volume of Leydig cells in cryptorchid testes and concluded that there was a reduced responsiveness to ICSH. Llaurado \& Dominguez (1963) treated unilaterally cryptorchid rats with human chorionic gonadotrophin (HCG). Such treatment increased the production of $17 \alpha$-hydroxyprogesterone, androst-4-ene-3,17-dione and testosterone by the scrotal testis in vitro but had no significant effect on the cryptorchid testis. They suggested that the limit in response to gonadotrophin is much lower in the cryptorchid testis than in the scrotal testis.

In a recent study, Liptrap \& Raeside (1970) reported that dehydroepiandrosterone (DHA) and oestrogen excretion of bilaterally and unilaterally cryptorchid boars did not differ appreciably from that of normal boars. Since urinary DHA and oestrogens are of testicular origin in the boar (Velle, 1958; Huis in't Veld, Louwerens \& Reilingh, 1961; Raeside, 1965; Glark, Raeside \& Solomon, 1965), the results suggested that the pig is a species in which the abdominal temperature does not affect the normal level of steroidogenesis by the testis. The present study was carried out to determine if the cryptorchid testis of the boar is able to respond to increased levels of gonadotrophins, as does the scrotal testis.

\section{MATERIALS AND METHODS}

Gryptorchid animals used in this study were obtained from a specially inbred strain of Yorkshire pigs of the Ganada Department of Agriculture. The breeding background of this cryptorchid herd has been outlined by Fredeen \& Newman (1968).

Complete and continuous urine collections, free of faecal contamination, were obtained from the boars while confined in a metabolism crate modified from that described by Welch, Gordts \& Vander Noot (1964). Urine was collected at 48-hr intervals, except during the period of daily treatment with 2000 i.u. of HcG (Pregnyl; Organon Inc., Montreal) when 24-hr collections were taken. The urine volume was measured and an aliquot was filtered through glass wool and stored at $4^{\circ} \mathrm{C}$ for 3 to 4 days, or at $-15^{\circ} \mathrm{C}$ for longer periods.

Dehydroepiandrosterone ( $3 \beta$-hydroxyandrost-5-en-17-one) determinations were carried out using a modified method of Fotherby (1959), as described by Raeside (1965). The results for total oestrogens in the urine samples were estimated with the procedure outlined by Raeside (1963). For convenience, all results are reported in $\mathrm{mg} / 24 \mathrm{hr}$. Statistical comparisons with control levels for each boar were made using Student's $t$ test (Snedecor, 1956).

The scrotal testis in each of two unilaterally cryptorchid boars, which were under pentobarbital sodium (Diabutal; Diamond Laboratories, Des Moines, Iowa) anaesthesia, was removed through an incision made on the ventral surface of the scrotum. Hemicastration of two normal boars was carried out in a similar manner. The abdominal testis in two additional unilaterally cryptorchid boars and one abdominal testis from each of two bilaterally cryptorchid boars were excised through flank incisions. Boars were returned to the collection crate within $36 \mathrm{hr}$ of surgery. 


\section{RESULTS}

A summary of the values for DHA and oestrogen excretion following hemicastration of both normal and cryptorchid boars is given in Table 1. Similar values during treatment with HCG are shown in Table 2.

Following removal of one testis from each of two normal boars $(3354,3356)$, the urinary levels of DHA and oestrogen did not differ significantly from those of control samples. Values approaching control levels were noted in the first sample collected after surgery, indicating a rapid compensation by the remaining testis. Removal of the scrotal testis from each of two unilaterally cryptorchid boars $(3391,3392)$ resulted in a statistically significant drop in

TABLE 1

URINARY DEHYDROEPIANDROSTERONE (DHA) AND OESTROGEN EXGRETION OF NORMAL AND GRYPTORGHID BOARS AFTER HEMICASTRATION

\begin{tabular}{|c|c|c|c|c|c|c|}
\hline $\begin{array}{l}\text { Boar } \\
\text { no. }\end{array}$ & $\begin{array}{l}\text { Cryptorchid } \\
\text { condition }\end{array}$ & $\begin{array}{c}\text { Age } \\
\text { (months) }\end{array}$ & Treatment & $\underset{(m g / 24 h r)}{D H A}$ & $\begin{array}{l}\text { Oestrogen } \\
(m g / 24 h r)\end{array}$ & $n$ \\
\hline 3354 & None & 22 & $\begin{array}{l}\text { Control } \\
\text { Hemicastration }\end{array}$ & $\begin{array}{l}76.54 \pm 7.38 \\
61.28 \pm 5.98\end{array}$ & $\begin{array}{ll}15.55 & \pm 2.55 \\
12.79 & \pm 1.24\end{array}$ & $\begin{array}{l}4 \\
5\end{array}$ \\
\hline 3356 & None & 22 & $\begin{array}{l}\text { Control } \\
\text { Hemicastration }\end{array}$ & 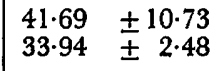 & $\begin{aligned} 12.67 & \pm 3.81 \\
7.62 & \pm 0.76\end{aligned}$ & $\begin{array}{l}5 \\
5\end{array}$ \\
\hline 3391 & Unilateral & 15 & $\begin{array}{l}\text { Control } \\
\text { Hemicastration (scrotal) } \\
2 \text { months after surgery }\end{array}$ & $\begin{array}{l}39.43 \pm 9.32 \\
21.96^{*} \pm 3.19 \\
30.26 \quad \pm 2.54\end{array}$ & $\begin{array}{ll}16.35 & \pm 5.51 \\
5.79 * & \pm 0.83 \\
8.69 & \pm 0.72\end{array}$ & $\begin{array}{l}4 \\
6 \\
5\end{array}$ \\
\hline 3392 & Unilateral & 16 & $\begin{array}{l}\text { Control } \\
\text { Hemicastration (scrotal) } \\
2 \text { months after surgery }\end{array}$ & $\begin{array}{l}23 \cdot 38 \pm \pm 4 \cdot 11 \\
7 \cdot 26^{* *} \pm 0.50 \\
24.70 \pm 5.38\end{array}$ & $\begin{array}{l}9.81 \pm 1.24 \\
3.75^{* *} \pm 0.50 \\
4.97^{*} \pm 0.63\end{array}$ & $\begin{array}{l}5 \\
5 \\
5\end{array}$ \\
\hline 3397 & Unilateral & 16 & $\begin{array}{l}\text { Control } \\
\text { Hemicastration (abdom.) } \\
2 \text { months after surgery }\end{array}$ & $\begin{array}{l}29.60 \\
22.37 \\
20.83 \\
20.13 .96 \\
\pm 3.82\end{array}$ & $\begin{array}{ll}9.97 & \pm 4.94 \\
8.36 & \pm 1.02 \\
8.46 & \pm 1.82\end{array}$ & $\begin{array}{l}4 \\
5 \\
5\end{array}$ \\
\hline 3394 & $\begin{array}{l}\text { Unilateral } \\
\text { (pneumonia) }\end{array}$ & 15 & $\begin{array}{l}\text { Control } \\
\text { Hemicastration (abdom.) } \\
2 \text { months after surgery }\end{array}$ & 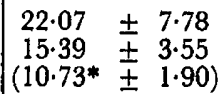 & $\begin{array}{cc}7.57 & \pm 1.88 \\
5.98 & \pm 1.59 \\
(3.94 * & \pm 0.54)\end{array}$ & $\begin{array}{l}4 \\
7 \\
5\end{array}$ \\
\hline 3388 & Bilateral & 20 & $\begin{array}{l}\text { Control } \\
\text { Hemicastration (abdom.) } \\
2 \text { months after surgery }\end{array}$ & $\begin{array}{l}44.35 \\
40.64 \\
44.69 \\
4.8 .45 \\
\pm 10.87\end{array}$ & $\begin{array}{l}4.42 \pm \pm 0.46 \\
2.73^{*} \pm 0.49 \\
8.78^{*} \pm 2.14\end{array}$ & $\begin{array}{l}6 \\
5 \\
5\end{array}$ \\
\hline 3385 & Bilateral & 23 & $\begin{array}{l}\text { Control } \\
\text { Hemicastration (abdom.) } \\
2 \text { months after surgery } \\
4 \text { months after surgery }\end{array}$ & $\begin{array}{r}20.80 \pm 1.56 \\
14 \cdot 65^{*} \pm 3 \cdot 23 \\
7.98^{* *} \pm 0.53 \\
10 \cdot 06^{* *} \pm 0.44\end{array}$ & $\begin{array}{r}11 \cdot 61 \pm 1.45 \\
5 \cdot 23^{* *} \pm 0.93 \\
5 \cdot 43^{* *} \pm 0.24 \\
5.29 * * \pm 0.37\end{array}$ & $\begin{array}{l}5 \\
5 \\
5 \\
5\end{array}$ \\
\hline
\end{tabular}

$n$, number of 48-hr samples; \pm , standard error of the mean.

$* P<0.05 ; * * P<0.01$.

hormone levels. By 2 months, the DHA and oestrogen values for these animals were within pre-operative levels, apart from the oestrogen level of one boar. When the abdominal testis was removed from each of two unilaterally cryptorchid boars $(3397,3394)$, no statistically significant reduction in hormone excretion occurred. For boar 3394, a severe chronic pneumonia is thought to have been responsible for the lower steroid excretion seen 2 months after surgery. The results following excision of one abdominal testis from each of two bilaterally cryptorchid boars $(3388,3385)$ showed a lowering in urinary steroid levels, with the exception of DHA excretion in one boar. In this animal, 
the DHA values remained high while oestrogen levels returned to higher than pre-operative levels by 2 months. In the other animal, the steroid values at 2 months, and at 4 months, had not returned to control levels.

Treatment of two bilaterally cryptorchid boars $(3415,3385)$ with 2000 i.u. of HGG daily for 5 days had no significant effect (Table 2) in elevating the amounts of DHA and oestrogens in the urine of one boar (3415), and only a slightly significant effect in the second boar (3385). This was in marked contrast to the effect of the same treatment in a normal boar (3351). Administration of HCG resulted in a highly significant elevation in the amounts of oestrogens and

TABLE 2

URINARY DEHYDROEPIANDROSTERONE (DHA) AND OESTROGEN EXGRETION OF NORMAL AND GRYPTORGHID BOARS AFTER TREATMENT WITH HUMAN GHORIONIG GONADOTROPHIN (HCG)

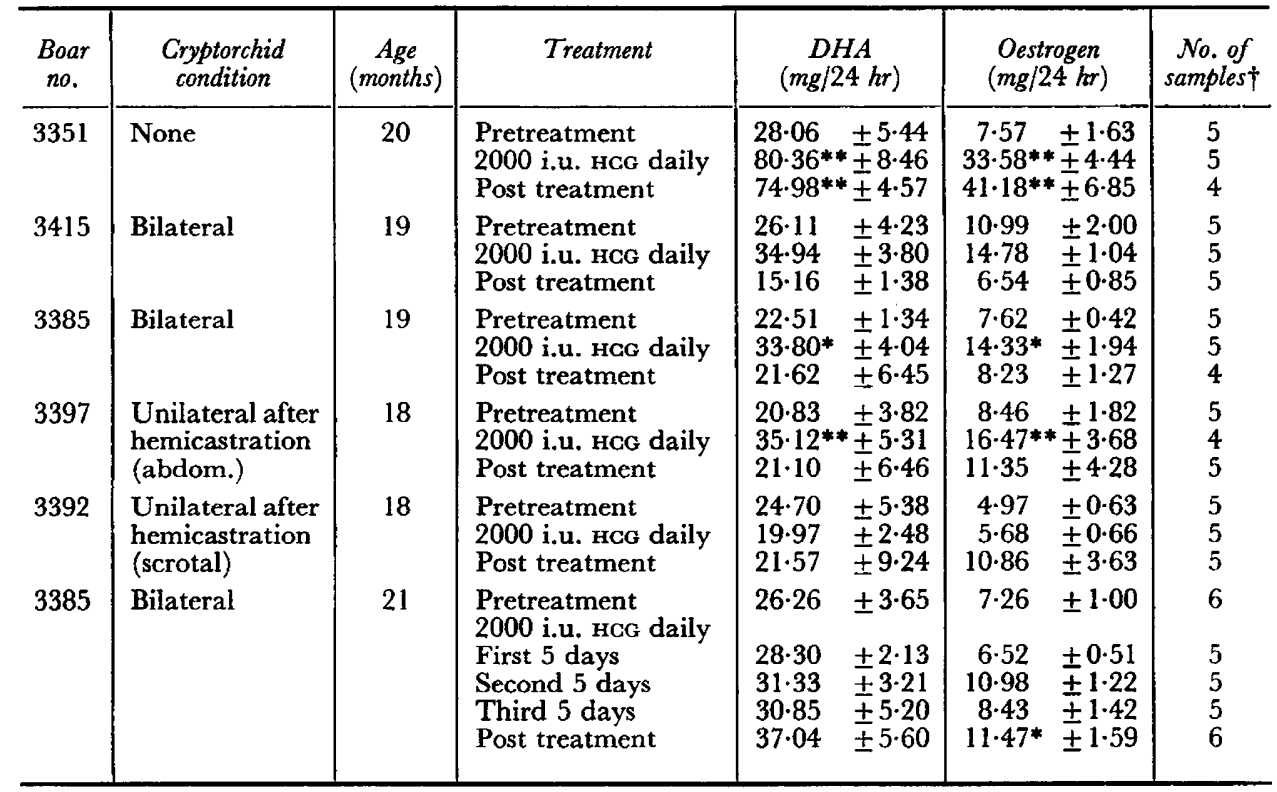

\pm , standard error of the mean.

${ }^{*} P<0.05 ; * * P<0.01$.

+ 48-hr samples, except during HCG treatment when 24-hr samples were collected.

DHA excreted by a unilaterally cryptorchid boar (3397) which had a scrotal testis remaining after hemicastration. No appreciable alteration in the steroid values was brought about by HCG in a unilaterally cryptorchid boar (3392) from which the scrotal testis had been removed. To determine if a longer treatment period with HCG would influence steroidogenesis by the abdominal testes, 2000 i.u. of HCG were administered daily for 15 days. The results in Table 2 suggest that even prolonged treatment did not significantly elevate DHA and oestrogen excretion in a bilaterally cryptorchid boar (3385).

\section{DISCUSSION}

Following hemicastration of two normal boars, there appeared to be a very 
rapid compensation in hormone production by the remaining testis. Similarly, in the unilaterally cryptorchid boars after removal of the cryptorchid testis, there was no statistically significant drop in the excretory values of DHA and oestrogens. The relatively large standard error of the mean, for all animals, reflects the marked daily variation in DHA and oestrogen excretion by normal and cryptorchid boars, and has been commented upon previously (Liptrap \& Raeside, 1970). When only a cryptorchid testis remained, following removal of the contralateral scrotal testis of unilaterally cryptorchid boars, there was a statistically significant drop in urinary steroid values. Two months after operation, the DHA and oestrogen values had risen to within control levels. These results suggest that the scrotal testis was able to compensate rapidly when the contralateral testis was removed from the normal or unilaterally cryptorchid boars. However, the cryptorchid testis of the unilaterally cryptorchid boar required a longer period of time in order to reach rates of production of DHA and oestrogens that were comparable to presurgical levels. In the unilaterally cryptorchid boar, the scrotal testis would seem to make the major contribution to the urinary steroid levels measured. Steroid production following hemicastration in the bilaterally cryptorchid animals seemed more variable. No explanation for this finding can be given from histological examination of the testes. Further work directed to distinguishing between a genetic effect and the influence of temperature upon steroidogenesis may provide an answer.

Previous reports (Raeside, 1965; Liptrap \& Raeside, 1968) and the results for the control boar in the present study indicate that the testes of the normal boar will respond to injections of HCG by greatly increasing the amounts of DHA and oestrogens excreted in the urine. The data in Table 2 indicate that the scrotal testis of the unilaterally cryptorchid boar is also capable of responding to HCG treatment. The cryptorchid testes of unilaterally and bilaterally cryptorchid boars showed only a limited increase in steroidogenesis, as reflected by DHA and oestrogen excretion, there being a statistically significant response $(P<0.05)$ noted in only one animal. Similar results were obtained when HCG was injected for a longer period of time in a bilaterally cryptorchid boar. Llaurado \& Dominguez (1963) have suggested that the limit in enzymatic response to gonadotrophin is lower for the cryptorchid testis than for the scrotal testis. The poor response by the cryptorchid testes of the boar to injections of HCG lends further support to this suggestion.

Although unilaterally and bilaterally cryptorchid boars are able to excrete DHA and oestrogens in amounts that are comparable to those of normal boars (Liptrap \& Raeside, 1970), the present results suggest that further stimulation of endocrine activity, with either endogenous or exogenous gonadotrophins, is limited. With time, the cryptorchid testis of the boar is generally able to compensate for the loss of the contralateral testis but is not able to respond to gonadotrophic stimulation with HCG in the manner exhibited by the scrotal testis. Eik-Nes (1964) has reviewed the evidence suggesting that gonadotrophins may stimulate steroid metabolism by affecting distinct enzymes using steroids as substrates in a short period of time (minutes), and by affecting protein synthesis in the gonad over a longer period of time (days). Further work is required to determine if the difference in time of response to endogenous 
gonadotrophin stimulation between scrotal and cryptorchid testes reflects these two orders of increased steroid metabolism. The cryptorchid boar may be a suitable model for examining the short and long term effects of gonadotrophins upon steroid biosynthesis.

\section{ACKNOWLEDGMENTS}

The authors wish to express thanks to Mrs G. Doig and Mrs P. Patterson for their technical assistance. This research was supported by the Ontario Department of Agriculture and Food and the Canada Department of Agriculture.

\section{REFERENCES}

Ceark, A. F., Raeside, J. I. \& Solomon, S. (1965) Studies on the urinary excretion of 17-ketosteroids by the domestic pig. Endocrinology, 76, 427.

CLEGG, E. J. (1960) Some effects of artificial cryptorchidism on the accessory reproductive organs of the rat. F. Endocr. 20, 210.

EIK-NEs, K. B. (1962) Secretion of testosterone in anaesthetized dogs. Endocrinology, 71, 101.

EIK-Nes, K. B. (1964) Effects of gonadotrophins on secretion of steroids by the testis and ovary. Physiol. Rev. 44, 609.

EIK-NEs, K. B. (1966) Secretion of testosterone by the eutopic and the cryptorchid testes in the same dog. Can. 7. Physiol. Pharmac. 44, 629.

Engbera, H. (1949) Investigations on the endocrine function of the testicle in cryptorchidism. Proc. $R$. Soc. Med. 42, 652 .

Fotherby, K. (1959) A method for the estimation of dehydroepiandrosterone in urine. Biochem. $\mathcal{F}$. 73, 339.

Fredeen, H. T. \& Newman, J. A. (1968) Cryptorchid condition and selection for its incidence in Lacombe and Canadian Yorkshire pigs. Can. F. Anim. Sci. 48, 275.

Free, M. J., Vera Cruz, N. C., Johnson, A. D. \& Gomes, W. R. (1968) Metabolism of glucose-1-14C and glucose $-6-{ }^{14} \mathrm{C}$ by testis tissue from cryptorchid and testosterone propionate treated rabbits. Endocrinology, 82, 183.

HALL, P. F. (1965) Influence of temperature upon the biosynthesis of testosterone by rabbit testis in vitro. Endocrinology, 76, 396.

Huis in't Veld, L. G., Louwerens, B. \& Reilingh, W. (1961) Neutral 17-ketosteroids in porcine urine. Nature, Lond. 191, 175.

Johnson, D. C. (1966) The use of non-castrate parabiotic rats for the evaluation of plasma gonadotrophins. Acta endocr., Copenh. 51, 269.

KARG, H. \& KRONTHALER, O. (1960) Histometrische Untersuchungen am hormonproduzierenden Interstitialgewebe von Hoden kryptorchider Tiere. Zentbl. VetMed. 7, 595.

Liptrap, R. M. \& RAEside, J. I. (1968) Effect of corticotrophin and corticosteroids on plasma interstitial cell-stimulating hormone and urinary steroids in the boar. $\mathcal{F}$. Endocr. 42, 33.

Liptrap, R. M. \& RAzside, J. I. (1970) Urinary steroid excretion in cryptorchidism in the pig. $\mathcal{F}$. Reprod. Fert. 21, 293.

Llaudrado, J. G. \& Dominguez, O. V. (1963) Effect of cryptorchidism on testicular enzymes involved in androgen biosynthesis. Endocrinology, 72, 292.

Morzhead, J. R. \& Morgan, C. F. (1967) Hormone production by experimental cryptorchid rat testes as indicated by radioautographic studies of the seminal vesicles and coagulating glands. Fert. Steril. 18, 232.

RAEsIDE, J. I. (1963) A procedure for the chemical determination of estrone and estradiol-17 $\beta$ in the urine of nonpregnant sows. Can. 7. Biochem. Physiol. 41, 2013.

RARside, J. I. (1965) Urinary excretion of dehydroepiandrosterone and oestrogens by the boar. Acta endocr., Copenh. 50,611.

SNedecor, G. W. (1956) Statistical methods, p. 45. Iowa State University Press, Ames, Iowa.

Steingerger, E. \& Ducketr, G. E. (1966) Pituitary "total" gonadotropins, Fse and LH in orchiectomized or cryptorchid rats. Endocrinology, 79, 912.

VELLE, W. (1958) Undersokelser over naturlig forekommende estrogener hos drevtyggere og gris. Thesis, Oslo.

Welch, J. G., Cordts, R. H. \& Vander Noot, G. W. (1964) Swine metabolism unit for 100 to 200 pound barrows. F. Anim. Sci. 23, 183. 